\title{
Study of Initial Colonization by Environmental Microorganisms in the Russian Segment of the International Space Station (ISS)
}

Ulrich Reidt ${ }^{1}$, Andreas Helwig ${ }^{1}$, Lutz Plobner², Veronika Lugmayr ${ }^{2}$, UlrichTreutlein ${ }^{2}$, Sergey Kharin ${ }^{3}$, Yuri Smirnov $^{3}$, Natalia Novikova ${ }^{3}$, Joachim Lenic ${ }^{4}$, Viktor Fetter ${ }^{5}$, and Thomas Hummel ${ }^{5}$

\begin{abstract}
${ }^{1}$ Airbus Group Innovations, Department TX4 - Electronics, Communications and Intelligent Systems, Munich, Germany; ${ }^{2}$ Agrobiogen GmbH, Hilgertshausen, Germany; ${ }^{3}$ State Scientific Center of the Russian Federation Institute of Biomedical Problems (IBMP) of the Russian Academy of Sciences, Moscow, Russia; ${ }^{4}$ Deutsches Zentrum für Luft- und Raumfahrt (DLR), Department RD-PS, Bonn, Germany; ${ }^{5}$ Airbus Defence and Space, Department TEB 22, TO53, Friedrichshafen, Germany
\end{abstract}

\begin{abstract}
In this report, we describe the initial colonization of environmental microorganisms associated with ISS on four different materials (Nomex, cable labeling material, printed circuit board, and aluminum), which are commonly used at the ISS. Material substrates were placed in the Russian segment of the ISS in a Target Book for 135 days. After the incubation, the Target Book was analyzed on Earth by determining colony-forming units and identifying the microorganisms by rRNA gene sequencing. The highest cell concentrations and widest biological diversity were on the polymer materials, such as Nomex and cable labeling material. Additional molecular biological identification revealed the following organisms as typical pioneer microorganisms: Staphylococcus spp., Bacillus spp., Streptococcus spp., Cladosporium spp.,
\end{abstract}

Key words: International Space Station; Nomex; Polymer Material; Bacteria; Fungi; rRNA Gene; Initial Colonization; Biodegradation; Biodeterioration

Correspondence to: Ulrich Reidt Electronics, Communications, and Intelligent Systems

Airbus Group Innovations, Department TX4

Munich, Germany

Telephone: +49 (0) 89.607-26675

Fax: +49 (0) 89.607-24001

E-mail: ulrich.reidt@airbus.com
Sphingomonas spp., Micrococcus luteus, and Stenotrophomonas maltophilia.

\section{INTRODUCTION}

The International Space Station (ISS) is a closed-habitat with specific conditions to ensure the safety and good living settings for the crew. High humidity, temperature between $18-25^{\circ} \mathrm{C}$, and adequate sources of organic material provide an ideal basis for the uncontrolled growth of microorganisms (Bogatova et al., 2009). This growth of microorganisms can be a serious problem for the health of the crew, especially during long space missions - for example, a manned mission to Mars (Pierson, 2001; Novikova et al., 2009). Therefore, it is essential to detect biological contaminants at an early stage and take steps to prevent their growth. Before starting, it is of the utmost importance to observe the changes in microbial dynamics in the ISS, as well as study the influence of microgravity on their survival and proliferation. The initial experiments describing the microbiological environment in outer space were undertaken at the Mir Space Station (Novikova et al., 2009; Novikova, 2004). On the Mir Space Station, 234 different species of bacteria and fungi were identified, and some of them populated specific ecological niches (Novikova, 2004). A preferred location for colonization was the humidity condensate that accumulated behind the panels at Mir. Several of these condensates were collected and a 
thorough analysis was followed on Earth. A large variety of cultivable organisms were detected by classical culturing techniques, including strains of Escherichia coli, Serratia marcescens, and a Legionella species (Ott et al., 2004). Air and surface samples were analyzed by different molecular biological and biochemical techniques. The bacteria from the air samples were mainly Gram-positive bacteria of the family Staphylococcaceae. Gramnegative bacteria were mainly isolated in water samples obtained from the condensates (Kawamura et al., 2001). Over the 15 years of operation of the Mir Space Station, 108 bacterial and 126 fungal species were isolated and analyzed (Novikova, 2004). The genera Staphylococcus, Micrococcus, Corynebacterium, and Bacillus were the most frequently identified bacteria, and Penicillium, Aspergillus, and Cladosporium were the prevalent fungi. Thus, microorganisms at the Mir Space Station found a proper milieu for spreading or accumulating on various materials. Depending on the substrate, the microorganisms may damage the shell structure, cabin interior, and equipment (Viktorov et al., 1992).

A new chapter in manned spaceflight began with the permanent occupation of humans in ISS. However, in the course of the commissioning of the ISS, microorganisms traveled as "blind passengers" to the habitat in orbit. The origin of this colonization was the crew and the hardware itself. Novikova and coworkers reported that the microorganisms originated primarily from the skin, mucous membranes, upper respiratory tract, mouth, nasal passage, and the gastrointestinal tract (Novikova et al., 2006). Normally, most of these human commensals do not represent a serious health hazard, but in some immunosuppressive cases these seemingly harmless organisms can trigger disease or allergies. As early as the 1970s, it has been known that during spaceflight, depression of lymphocyte function occurs, which results in a reduction of the immune response (Cogoli, 1993). The reasons for this physiological phenomenon are psychosocial and physical stresses, high G-forces at launch and landing, radiation in outer space, sleeplessness, and microgravity (Gueguinou et al., 2009). Thus, it is speculated that the crew represents an "open door" for an opportunistic infection during a long space mission.

A further aspect concerning the safety of the crew is the biodegradation of material and equipment by microorganisms. Studies from the Mir Space Station indicate that biologicallyinduced corrosion and biodeterioration of materials is a serious problem. Under conditions of uncontrolled growth, bacteria and fungi degrade and destroy different materials - such as metals and polymers (Klintworth et al., 1999). Early results from human space missions revealed that 58 bacteria and 36 fungi species could be isolated from space vehicles, and many of them attacked and destroyed polymeric materials (Viktorov et al., 1992; Novikova, 2004; Horneck et al., 2010). First studies at the initial commissioning and human occupation of the ISS were undertaken. To obtain a comprehensive picture of the cultivable microbial diversity at an early stage of the ISS, samples were taken from a reusable cargo container of the Space Shuttle, and also from water, air, and selected surfaces of the ISS. In these studies, 63 different bacterial strains were identified. Of those microorganisms, Grampositive strains of the species Staphylococcus aureus, Staphylococcus pasteuri, and Micrococcus luteus dominated (Castro et al., 2004). At a slightly later point in time of human occupation, samples taken in the Russian segment were analyzed (Figure 1). Grampositive stains of Bacillus subtilis, Staphylococcus epidermidis, and Staphylococcus saprophyticus were also identified (Rakova et al., 2005). Both studies demonstrate that Gram-positive strains may play key roles as pioneer microorganisms in the colonizing of an unoccupied ecological environment (Novikova et al., 2009).

In this report, a settlement of bacteria and fungi on select ISS materials that are exposed as witness plates at the ISS was investigated. The study was part of a larger research project from Deutsches Zentrum für Luft- und Raumfahrt (DLR) called "E-Nose," which was designed to develop a new rapid method of, and instrumentation for, the detection of microorganisms directly in a space station habitat. In this study, a Target Book with different sample materials was launched to the ISS and placed in the Zvezda Service Module at the Russian segment. After an incubation time of 135 days, the Target Book was returned to Earth and immediately transported to a laboratory for analysis. Wipe samples and contact culture plates were taken from all materials at the Target Book and corresponding cultures were analyzed by microbiological and 


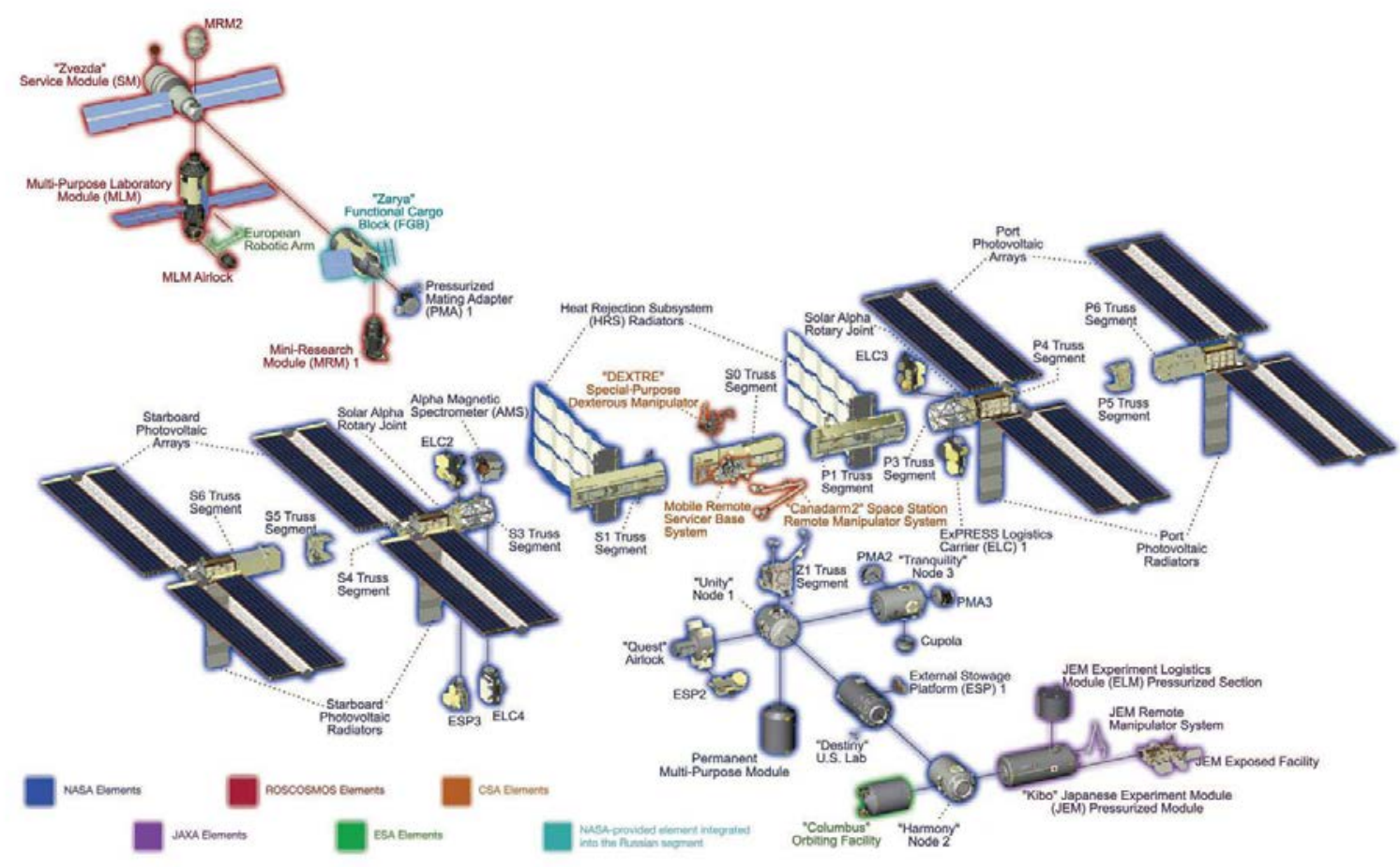

Figure 1. Schematic drawing of the ISS (in red) of the Russian segment with the Zvezda Service Module where the Target Book was placed for 135 days (NASA (2012) International Space Station Calendar). Retrieved from http://www.nasa.gov/pdf/615398main_2012_iss_calendar.pdf (Accessed 11/30/14).

molecular biological techniques. In this report, we summarize microorganisms colonizing the sterile Target Book containing four different materials in a closed habitat in outer space.

\section{MATERIALS AND METHODS}

\section{Manufacturing and Preparation of the Target Book}

The Target Book was composed of aluminum (ALU) and the dimensions were 325 $\mathrm{mm}$ by $255 \mathrm{~mm}$. It contained 12 round targets composed of 4 different material substrates with a diameter of $40 \mathrm{~mm}$ each, corresponding to a surface area of $12.56 \mathrm{~cm}^{2}$. All substrates were covered by a coarsely meshed grid with a diameter pore size of $7 \mathrm{~mm}$ to prevent accidental touching of the targets. The materials were successively attached at target positions: A1-A3 non-anodized aluminum (ALU); B1-B3 Nomex - a special flame resistant aramid polymer tissue; C1-C3 printed circuit board (PCB) material; and D1-D3 cable labeling material (CLM) - a polyimide (Figure 2). All four materials were selected based on original materials used within the ISS, and were tested in the laboratory according to their known growthinhibiting effects (data not shown). The materials on the Target Book were first sterilized with 3\% hydrogen peroxide for 15 min, and second by exposure of UV light for 30 $\min$. At the end of the sterilization procedure, the Target Book was sterile-packed for transport to the ISS. Before packaging, the Target Book was checked for sterility by swapping the material substrates with sterile wet swabs under a clean bench. After sampling, the swabs were directly streaked on Tryptic Soy Agar (TSA) and Czapek Dox Agar (CDA) for a sterility testing (Digestive Ferments Company, Difco Laboratories, 1953). CDA culture plates were then incubated at $28^{\circ} \mathrm{C}$ for 5 days and TSA plates were incubated at $37^{\circ} \mathrm{C}$ for 2 days. No microbial growth was found after incubation of the culture plates; hence we can make the assumption that all materials at the Target Book were sterile.

\section{Culture Media and Culture Conditions}

Media were obtained from Sigma-Aldrich and Carl Roth, Germany, and were prepared according to the formula of Yeast Extract Agar 


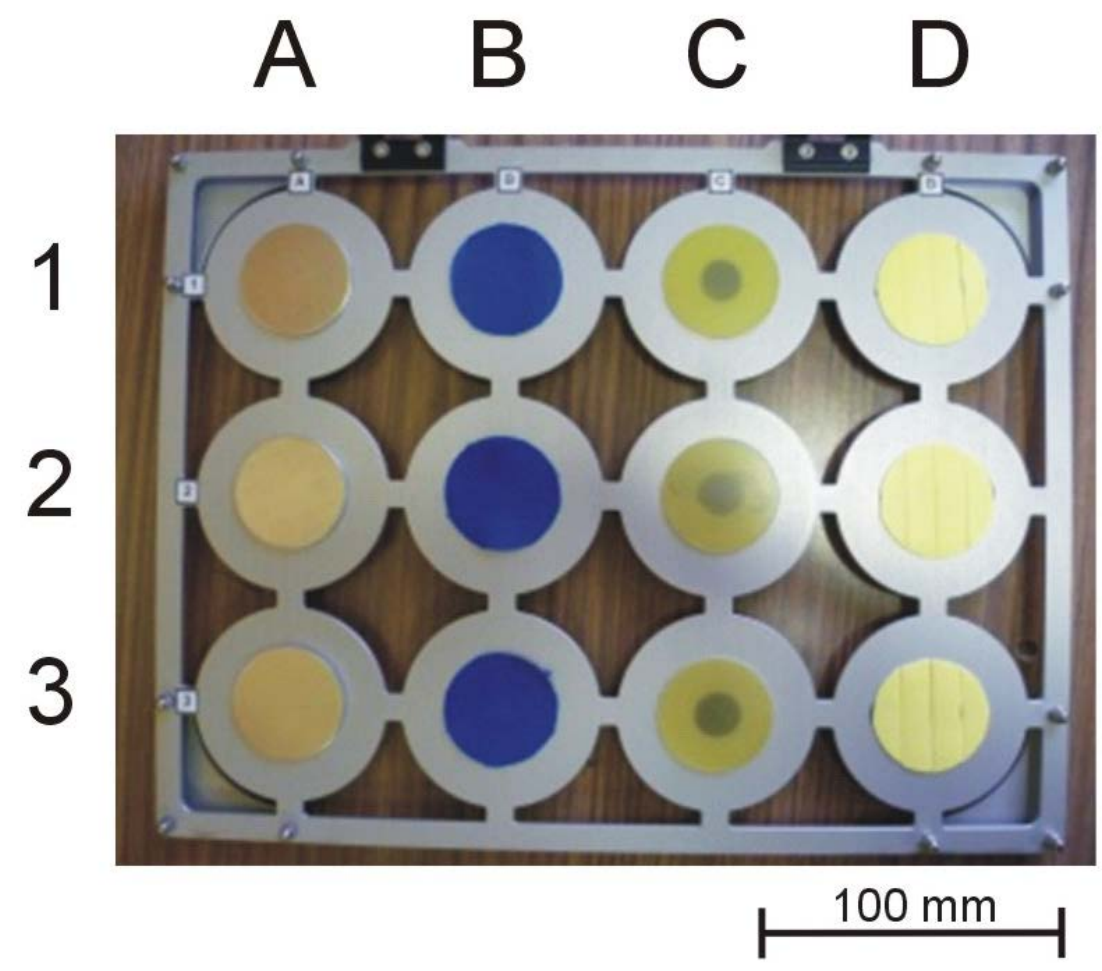

Figure 2. Illustration of the Target Book with four different materials: A1-A3 non-anodized aluminum (ALU), B1-B3 Nomex, C1-C3 printed circuit board (PCB) material, and D1-D3 cable labeling material (CLM).

(YEA), Sabouraud-4\%-Glucose-Agar (SGA), Reasoner's 2A Agar (R2A), and Tryptic Soy Agar (TSA) (Digestive Ferments Company, Difco Laboratories, 1953). The dehydrated powders from all media were suspended in 1 liter of distilled water and were sterilized at $121^{\circ} \mathrm{C}$ for 15 minutes. After sterilization and cooling down to $45-50^{\circ} \mathrm{C}$, media was poured into Petri dishes. All culture plates were incubated at $20^{\circ} \mathrm{C}$ for 5 to 7 days, and the number of colony-forming units (CFU) was determined at the end of incubation.

\section{Sampling of Microorganisms from the Target Book}

The Target Book was opened under sterile conditions and all materials (A1-D3) were swabbed with a sterile wet swab obtained from Starplex Scientific Inc., Canada (Figure 3). The swabs were washed in $1 \mathrm{ml}$ sterile $\mathrm{NaCl}, 0.85 \%$ (W/V), and a dilution series from undiluted to 1:1000 was established for each swab wash solution. In the next step, $100 \mu \mathrm{l}$ from each dilution was streaked on R2A Agar (R2A), Tryptic Soy Agar (TSA), Yeast Extract Agar (YEA) and Sabouraud-4\%-Glucose-Agar (SGA). Contact plates were prepared with R2A Agar and Tryptic Soy Agar and were incubated between 5 and 7 days at $20^{\circ} \mathrm{C}$. Using the same method as for swab samples, colonies were counted on the contact plates.

\section{Nucleic Acid Extraction}

Fifty microorganisms were picked from the agar plates under a laminar flow hood with a sterile inoculation loop to produce the same numbers of pure cultures. After streaking the picked colonies, the culture plates were incubated at the same conditions, which were used for CFU determination. Then cells were transferred to appropriately labeled tubes with lysis buffer from nexttec ${ }^{\mathrm{TM}}$ 1-Step DNA Isolation Kit for Bacteria, obtained from Agrobiogen GmbH, Germany. For bacteria, the lysis and DNA purification was carried out according to the protocol of the nexttec ${ }^{\mathrm{TM}}$ Kits for Bacteria. After enzymatic lysis, the genomic DNA was purified with special spin columns (nexttec $^{\mathrm{TM}}$ cleanColumns). For fungi, the protocol of the nexttec ${ }^{\mathrm{TM}} 1$-step DNA Isolation Kit for Tissue \& Cells was modified. The enzymatic lysis was combined with an upstream mechanical disruption. The mechanical disintegration was performed in a reaction tube with glass beads ( $\mathrm{d}=0.5 \mathrm{~mm}$ ) by shaking in a high-frequency 3D Ribolyser ${ }^{\mathrm{TM}}$ from Hybaid, 


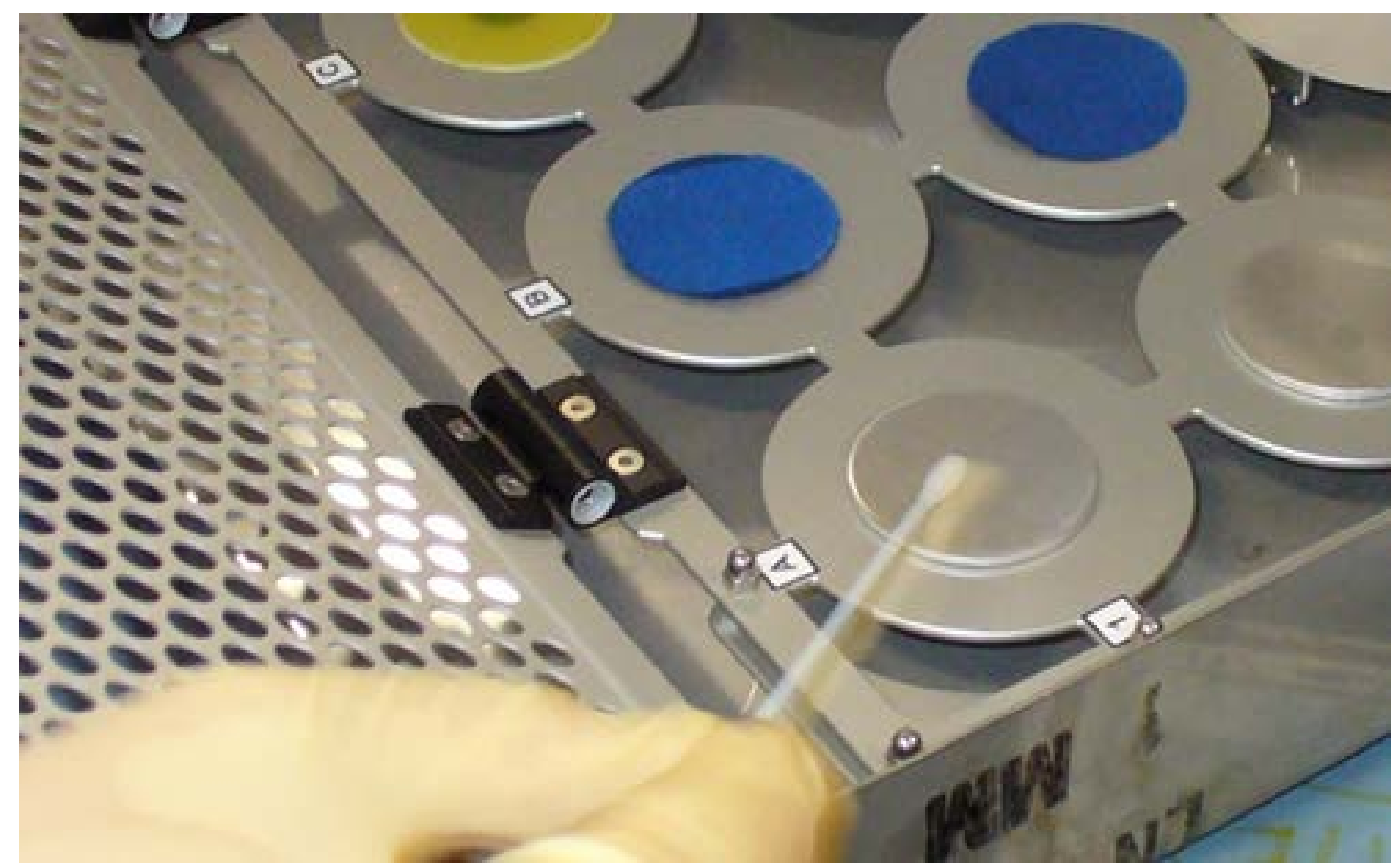

Figure 3. Back on Earth, swabbing the targets from the Target Book with a sterile wet swab to wipe off the biological load.

Germany for 15 seconds at a speed of $4 \mathrm{~m} / \mathrm{s}$. After lysis, DNA was purified by nexttec ${ }^{\mathrm{TM}}$ cleanColumns, as described in the protocols.

\section{PCR (Polymerase Chain Reaction) and Sequencing of PCR Products}

The PCR primer pairs for bacteria (P3MOD forward: 5'ATTAGATACCCTDGTAGTCC3`, PC5B reverse: 5`-TACCTTGTTACTT-3`) and fungi (NS1 forward: 5'GTAGTCATATGCTTGTCTC-3` and NS2 reverse: 5`-GGCTGCTGGCACCAGACTTGC3 ') were synthesized by Eurofins MWG Operon, Germany, using sequences obtained from the literature (White et al., 1990; Kuske et al., 1998). PCR mixtures contained $10 \mathrm{mM}$ Tris$\mathrm{HCl}$ (pH 8.3), $50 \mathrm{mM} \mathrm{KCl,} 1.5 \mathrm{mM} \mathrm{MgCl} 2,2.5$ $\mathrm{mM}$ each of the four deoxynucleotides, 100 pmol of each primer, $5 \mathrm{U} / \mu \mathrm{l}$ of Taq DNA polymerase (New England Biolabs, USA), and 2 $\mu l$ of genomic DNA as a template. Negative controls did not contain template DNA. The PCR assays were conducted in a TPersonal thermocycler (Biometra GmbH, Germany) with the following thermal profile: initial denaturation for $5 \mathrm{~min}$ at $95^{\circ} \mathrm{C}$, followed by 30 cycles of denaturation at $95^{\circ} \mathrm{C}$ for $20 \mathrm{~s}$, annealing at $45^{\circ} \mathrm{C}$ for $20 \mathrm{~s}$, extension at $72^{\circ} \mathrm{C}$ for $1 \mathrm{~min}$, and final extension at $72^{\circ} \mathrm{C}$ for $5 \mathrm{~min}$.
The amplified PCR products were separated in a $1.5 \%(\mathrm{~W} / \mathrm{V})$ agarose gel and stained with ethidium bromide. Agarose gels were prepared and run in $1 \times$ TAE buffer (50 x TAE: $242 \mathrm{~g}$ Tris-base, $57.1 \mathrm{ml}$ acetic acid, $100 \mathrm{ml} 0.5 \mathrm{M}$ EDTA, water to $1000 \mathrm{ml}, \mathrm{pH}$ 8.5). The PCR products were compared to a $1 \mathrm{~kb}$ DNA ladder (New England Biolabs, USA) to estimate their size. The results were scored as positive and negative by visual inspection. The reactions were purified by spin columns (QIAGEN $\mathrm{GmbH}$ ) and the PCR products were directly sequenced as a service from Eurofins MWG Operon, Germany using the same primer pairs as for amplification. The sequences from all PCR products were compared by Standard Nucleotide Basic Local Alignment Search Tool (BLAST) analysis against all available sequences, excluding model sequences and uncultured or environmental sample sequences (Benson et al., 1999).

\section{RESULTS}

On December 19, 2012, Soyuz TMA-07M launched from Baikonur Cosmodrome, Kazakhstan to the ISS for expedition 34/35. The crew consisted of Tom Marshburn (USA), Roman Romanenko (Russia), and Chris Hadfield (Canada) and the expedition lasted 
approximately six months. During this expedition, the Target Book was transported to the ISS as a part of the research project "ENose" (supported and initialized by DLR, Germany). After the Soyuz TMA-07M docked to the ISS and the commissioning (initial check of correct functions) of the equipment was completed, the sterile Target Book was placed at the Zvezda Service Module in the Russian segment of the ISS. The Target Book remained for 135 days in the environment of the ISS at panel \#221. After the end of the incubation period, the Target Book was packed in a sterile bag within a soft transport bag (Figures 4-5). On May 13, 2013, the Target Book was returned to Earth by a soft landing of Soyuz TMA-07M in the steppes of Kazakhstan. After landing, the Target Book was immediately removed from Soyuz, cooled to $4^{\circ} \mathrm{C}$, and transported to the laboratories of the Institute of Bio-Medical Problems (IBMP), Moscow, Russia for inspection. Subsequently, the Target Book was transported to the laboratories of Airbus Group Innovations, Munich, Germany without interruption of the cool conditions. The Target Book was opened under sterile conditions and CFUs were determined from all materials of the Target Book (A1-D3) by methods of surface swabbing and contact plates. The CLM had the highest CFU value (D1-D3), with an average washout cell number of $3.5 \mathrm{E}+04 \mathrm{CFU} / \mathrm{ml}$, followed by Nomex (B1-B3), with a cell number of $1.4 \mathrm{E}+04 \mathrm{CFU} / \mathrm{ml}$. No cells were found associated with the PCB material (C1$\mathrm{C} 3)$, and a low cell number of $1.1 \mathrm{E}+02 \mathrm{CFU} / \mathrm{ml}$ were identified on the ALU (A1-A3) substrate (Table 1).

For a more effective removal of the settled cells, contact plates were used after swabbing the surface of the material. The largest average CFU was associated with the CLM (D1-D3) with 57.3 cells, in contrast to a low average CFU for ALU (A1-A3) with 6.6 cells, and Nomex (B1-B3), with 5.6 cells. In addition, cells from the surface of the PCB material could be removed by contact plates, resulting in a low average cell number of 5.6 cells (Table 2 ).

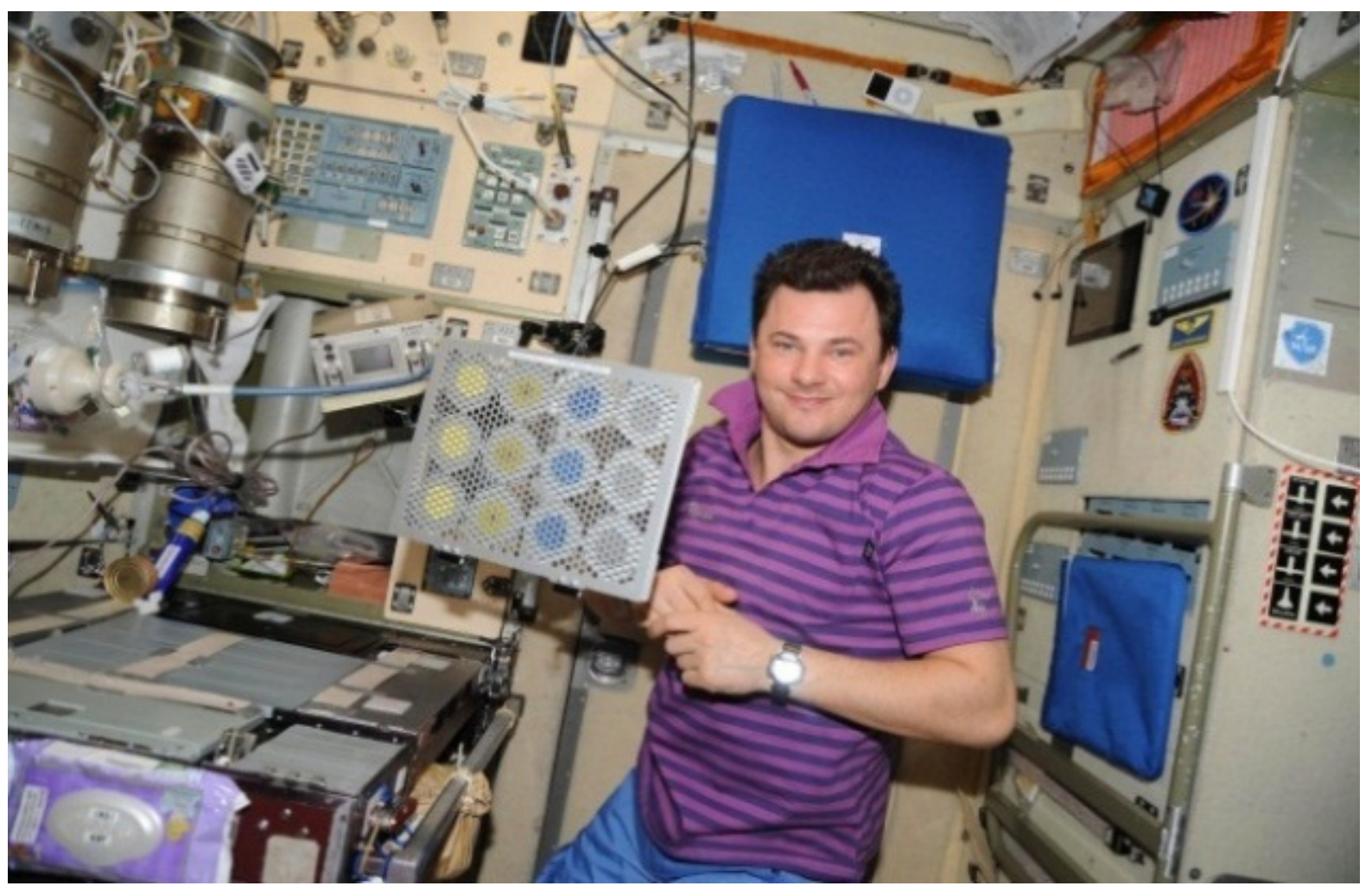

Figure 4. Commissioning of the Target Book by cosmonaut Roman Romanenko. In the right corner of the photograph, the soft transport bag (in blue) is shown at the wall of the ISS. 


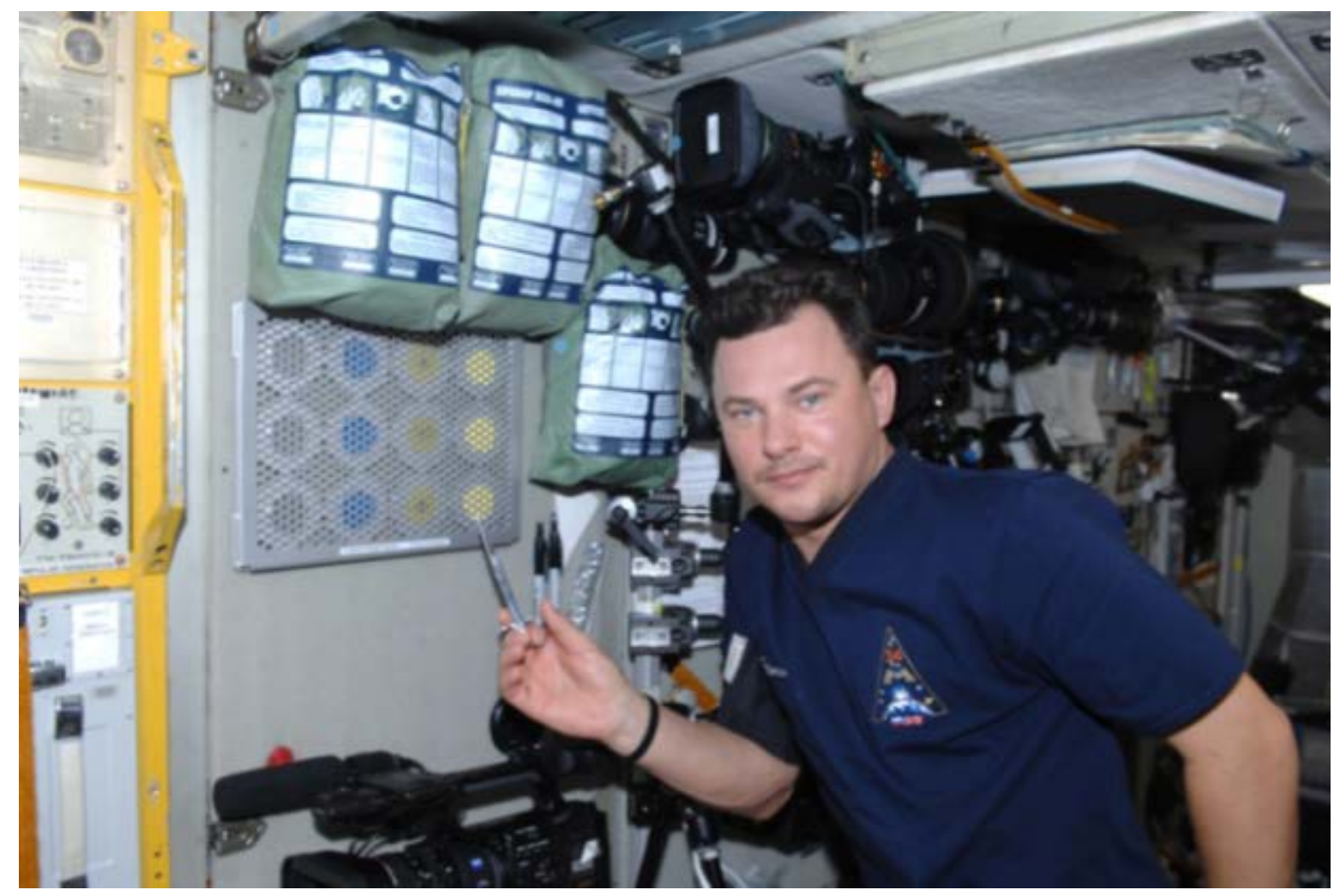

Figure 5. Placement of the Target Book in the Russian segment of the ISS (Zvezda Service Module) by cosmonaut Roman Romanenko.

In addition to the whole CFU count, the species were determined. Colonies were picked from across all culture plates to produce pure cultures for identifying strains. The picked colonies were chosen by colony morphology (e.g., shape and color), dominance at the culture plates, and distinguishing between bacteria or fungi. Care was taken to obtain pure cultures from all materials and across all plates. Genomic DNA was then isolated from each pure culture by using spin columns. In addition, for later BLAST analysis, PCR was used to amplify a $723 \mathrm{bp}$ fragment of the 16S rRNA gene from bacteria, and a 555 bp region of the 18S rRNA gene from fungi. All PCR products were compared by Standard Nucleotide BLAST analysis.

From 50 PCR products based from pure cultures, 46 bacterial or fungal strains were identified. Four fungal cultures -1 strain Phoma spp. and 3 strains Cladosporium spp. could only be identified by genus. In total, 39 bacterial and 7 fungal genera were determined. Gram-positive bacteria dominated, with 30 strains of the genera of Staphylococcus (11 strains), Micrococcus (5 strains), Bacillus (4 strains), and Streptococcus (2 strains). The genera Micrococcus and Streptococcus were represented exclusively by the species Micrococcus luteus and Streptococcus salivarius. On the other hand, the 11 Gramnegative bacteria were primarily represented by the species Sphingomonas phyllosphaerae, Sphingomonas pseudosanguinis, and Stenotrophomonas maltophilia (2 strains). For the fungi, the genus Cladosporium was dominant, and 7 other fungi were found once each (Alternaria smyrnii, Penicillium digitatum, Phoma spp., Coriolopsis gallica, Rhinocladiella atrovirens, Taphrina wiesneri, and Subplenodomus valerianae). Regarding biological diversity, most different species were identified on Nomex material (18 strains), followed by cable CLM (12 strains) and ALU (12 strains). The lowest diversity was found on PCB (3 strains), which also has the lowest CFU number on the contact plates. It is of interest that Micrococcus luteus and Bacillus spp. could be identified on all four materials. On three out of four materials (ALU, Nomex, and CLM), the genus Staphylococcus was detected (Table 3). 
Table 1. Colony forming units from the swabbing of each material by a surface area of $12.56 \mathrm{~cm}^{2}$ from the Target Book.

\begin{tabular}{|c|c|c|c|c|}
\hline & $\begin{array}{c}A \\
(A L U)\end{array}$ & $\begin{array}{c}\text { B } \\
\text { (NOMEX) }\end{array}$ & $\begin{array}{c}\mathrm{C} \\
(\mathrm{PCB})\end{array}$ & $\begin{array}{c}D \\
(\mathrm{CLM})\end{array}$ \\
\hline \multirow{5}{*}{1} & R2A: 50 & R2A:10020 & R2A: 0 & R2A: 1800 \\
\hline & TSA: 10 & TSA: 10 & TSA: 0 & TSA: 0 \\
\hline & YEA: 20 & YEA: 0 & YEA: 0 & YEA: 0 \\
\hline & SGA: 0 & SGA: 0 & SGA: 0 & SGA: 0 \\
\hline & $\sum: 80 \mathrm{CFU} / \mathrm{ml}$ & $\sum: 1.0 \mathrm{E}+04 \mathrm{CFU} / \mathrm{ml}$ & $\sum: 0 \mathrm{CFU} / \mathrm{ml}$ & $\sum: 1.8 \mathrm{E}+03 \mathrm{CFU} / \mathrm{ml}$ \\
\hline \multirow{5}{*}{2} & R2A: 0 & R2A: 1180 & R2A: 0 & R2A: 1060 \\
\hline & TSA: 0 & TSA: 2670 & TSA: 0 & TSA: 31280 \\
\hline & YEA: 0 & YEA: 70 & YEA: 0 & YEA: 740 \\
\hline & SGA: 0 & SGA: 0 & SGA: 0 & SGA: 0 \\
\hline & $\sum: 0 \mathrm{CFU} / \mathrm{ml}$ & $\sum: 3.9 \mathrm{E}+03 \mathrm{CFU} / \mathrm{ml}$ & $\sum: 0 \mathrm{CFU} / \mathrm{ml}$ & $\sum: 3.3 \mathrm{E}+04 \mathrm{CFU} / \mathrm{ml}$ \\
\hline \multirow{5}{*}{3} & R2A: 0 & R2A: 300 & R2A: 0 & R2A: 490 \\
\hline & TSA: 20 & TSA: 0 & TSA: 0 & TSA: 150 \\
\hline & YEA: 0 & YEA: 0 & YEA: 0 & YEA: 30 \\
\hline & SGA:10 & SGA: 0 & SGA: 0 & SGA: 100 \\
\hline & $\sum: 30 \mathrm{CFU} / \mathrm{ml}$ & $\sum: 3.0 \mathrm{E}+02 \mathrm{CFU} / \mathrm{ml}$ & $\sum: 0 \mathrm{CFU} / \mathrm{ml}$ & $\sum: 7.7 \mathrm{E}+02 \mathrm{CFU} / \mathrm{ml}$ \\
\hline$\varnothing$ & $1.1 \mathrm{E}+02$ & $1.4 \mathrm{E}+04$ & 0 & $3.5 \mathrm{E}+04$ \\
\hline
\end{tabular}

$\varnothing$ : average CFU obtained from all three material targets, $\sum$ : sum of CFU at one target material calculated from culturing plates, R2A: R2A Agar, TSA: Tryptic Soy Agar, YEA: Yeast Extract Agar, SGA: Sabouraud-4 \%Glucose-Agar

\section{DISCUSSION}

This experiment is studying the primary settlement of environmental microorganisms on four different materials routinely used in outer space at the ISS. Also, for the first time, we present the results of the biological diversity of the incipiently growth stage of microorganisms, which were spreads on the aramid polymer (Nomex), CLM, PCB material, and ALU. These results demonstrate that both polymers, Nomex and CLM, are proper bases for attachment and could provide a type of nutrient medium for the development of a biological community. One reason for this effect could be the roughness of both polymer materials. Nomex is a textile with a relatively large surface-based roughness, in contrast to the smooth surface of ALU and PCB (Ozgen, 2012). On the other hand, both materials provide a carbon source, in combination with high humidity and a favorable temperature for growth. Hence, polymers could be a very good substrate for the accumulation of microorganisms, in combination with naturally organic particles fallen at the materials ( $\mathrm{Gu}$, 2003).

In other studies, Pseudomonas aeruginosa, Ochrobactrum anthropic, Alcaligenes denitrificans, and Stenotrophomonas maltophilia (old nomenclature: Xanthomonas maltophila) were found specifically on different polymers used at the ISS, and it has been shown that biofilm formation of these microorganisms is responsible for polymer deterioration (Gu, 2007). In our study, we identified the Gramnegative bacterium Stenotrophomonas maltophilia on the substrates, Nomex, and CLM, 
Reidt et al. - Initial Colonization by Environmental Microorganisms in Russian ISS Segment

Table 2. Colony forming units by type of contact plate at a surface area of $12.56 \mathrm{~cm}^{2}$.

\begin{tabular}{ccccc}
\hline & A (ALU) & B (NOMEX) & C (PCB) & D (CLM) \\
\hline 1 & R2A: 4 & R2A: 7 & R2A: & R2A: 5 \\
& TSA: 2 & TSA: 2 & TSA: 3 & TSA: 16 \\
& $\sum: 6$ & $\sum: 9$ & $\sum: 3$ & $\sum: 21$ \\
& R2A: 6 & R2A: 2 & R2A: 0 & R2A:78 \\
& TSA: 3 & TSA: 0 & TSA: 5 & TSA: 45 \\
& $\sum: 9$ & $\sum: 2$ & $\sum: 5$ & $\sum: 123$ \\
& R2A: 2 & R2A: 5 & R2A: 2 & R2A: 8 \\
& TSA: 3 & TSA: 1 & TSA:7 & TSA: 20 \\
& $\sum: 5$ & $\sum: 6$ & $\sum: 9$ & $\sum: 28$ \\
\hline
\end{tabular}

$\varnothing$ : average CFU obtained from all three material targets, $\sum$ : sum of CFU at one target material calculated from culturing plates, R2A: R2A Agar, TSA: Tryptic Soy Agar

which indicates that this organism finds these substrates to be media providing excellent conditions for life. In the literature concerning fungal contamination, the species Aspergillus versicolor, Cladosporium cladosporioides, and Chaetomium spp. were isolated from biodegraded polymers such as polyimides (Gu et al., 1998). In this investigation, Cladosporium spp. was detected on the CLM, but Aspergillus spp. was not. We assumed that Aspergillus spp. could be not a classical pioneer organism of a new environment. An important aspect for the colonization of new materials is the capability of microorganisms to produce extracellular polymeric substances (EPS). These substances are high-molecular weight compounds secreted by microorganisms into the environment that allow them to attach to substrates (Donlan, 2002). Mauclaire and co-workers describe an attachment and the formation of EPS by Micrococcus luteus under microgravity conditions (Mauclaire and Egli, 2010). They found that microgravity has an effect on the physiological processes that induce bacterial attachment to form biofilms. In addition, they observed that Micrococcus luteus obtained from the ISS produces larger amounts of EPSs with a higher yield of biomass, combined with an accelerated growth, compared to naturally occurring strains from Earth. Our results also suggest that Micrococcus luteus attaches most effectively to various materials, which is due to the effective production of EPS and an accelerated growth rate. These results also indicate that sensitive and fast detection, in combination with the prevention of uncontrolled growing of microorganisms, is a very important 
Table 3. Identification of growth environmental microorganisms on the materials in the Target Book by rRNA gene sequencing.

\begin{tabular}{|c|c|c|c|}
\hline $\begin{array}{c}\text { A } \\
(\mathbf{A L U})\end{array}$ & $\begin{array}{c}\text { B } \\
(\text { NOMEX) }\end{array}$ & $\begin{array}{c}\mathrm{C} \\
(\mathbf{P C B})\end{array}$ & $\begin{array}{c}\mathrm{D} \\
(\mathrm{CLM})\end{array}$ \\
\hline $\begin{array}{l}\text { Enhydrobacter } \\
\text { aerosaccus }^{\mathrm{b}++, 2}\end{array}$ & $\underset{\mathrm{b},+, 3}{\text { Aerococcus viridans }^{-}}$ & Bacillus cohnii ${ }^{\mathrm{b},+, 1}$ & $\underset{\mathrm{b},+, 3}{\text { Aerococcus urinaeequi }}$ \\
\hline Micrococcus luteus ${ }^{\mathrm{b},+, 1}$ & Bacillus thuringiensis & Micrococcus luteus ${ }^{\mathrm{b},+, 3}$ & Bacillus simplex ${ }^{\mathrm{b},+, 3}$ \\
\hline Micrococcus luteus ${ }^{\mathrm{b},+, 2}$ & $\begin{array}{l}\text { Microbacterium } \\
\text { testaceum }^{\mathrm{b},+, 1}\end{array}$ & $\begin{array}{l}\text { Streptococcus } \\
\text { salivarius }^{b,+, 1}\end{array}$ & Micrococcus luteus ${ }^{\mathrm{b},+, 3}$ \\
\hline Rhodococcus jostii ${ }^{\mathrm{b},+, 1}$ & Micrococcus luteus ${ }^{\mathrm{b},+, 3}$ & - & $\underset{\mathrm{b},+, 2}{\text { Nocardioides simplex }}$ \\
\hline $\begin{array}{l}\text { Staphylococcus } \\
\text { arlettae }\end{array}$ & $\begin{array}{l}\text { Staphylococcus } \\
\text { epidermidis }{ }^{b,+, 2}\end{array}$ & - & $\underset{b,+, 3}{\text { Nocardioides simplex }}$ \\
\hline $\begin{array}{l}\text { Staphylococcus } \\
\text { equorum }^{\text {b,+,1 }}\end{array}$ & $\begin{array}{c}\text { Staphylococcus } \\
\text { haemolyticus }^{\mathrm{b},+, 2}\end{array}$ & - & $\begin{array}{l}\text { Staphylococcus } \\
\text { epidermidis }{ }^{b,+, 2}\end{array}$ \\
\hline $\begin{array}{l}\text { Staphylococcus } \\
\text { warneri }^{\mathrm{b},+, 3}\end{array}$ & $\begin{array}{l}\text { Staphylococcus } \\
\text { haemolyticus }^{\mathrm{b},+, 2}\end{array}$ & - & $\begin{array}{c}\text { Staphylococcus } \\
\text { warneri }^{\mathrm{b},+, 2}\end{array}$ \\
\hline- & $\begin{array}{l}\text { Staphylococcus } \\
\text { hominis }^{b,+, 1}\end{array}$ & - & $\begin{array}{l}\text { Streptococcus } \\
\text { salivarius }^{\mathrm{b},+, 2}\end{array}$ \\
\hline $\begin{array}{c}\text { Dyadobacter } \\
\text { alkalitolerans }^{\mathrm{b},-, 1}\end{array}$ & $\begin{array}{c}\text { Staphylococcus } \\
\text { saprophyticus }^{\mathrm{b},+, 3}\end{array}$ & - & - \\
\hline $\begin{array}{c}\text { Sphingomonas } \\
\text { phyllosphaerae }^{\mathrm{b},-, 1}\end{array}$ & $\begin{array}{l}\text { Staphylococcus } \\
\text { warneri }^{\text {b,+,2 }}\end{array}$ & - & Hymenobacter soli $^{\text {b,-,3 }}$ \\
\hline- & $\begin{array}{l}\text { Streptomyces } \\
\text { globisporus }^{\mathrm{b}+, 1}\end{array}$ & - & $\begin{array}{c}\text { Stenotrophomonas } \\
\text { maltophilia }{ }^{\mathrm{b},-, 2}\end{array}$ \\
\hline Alternaria smyrnii ${ }^{\mathrm{f}, 1}$ & & - & - \\
\hline Bacillus endophyticus & $\begin{array}{l}\text { Hymenobacter } \\
\text { aerophilus b,-,1 }^{\text {beropen }}\end{array}$ & - & Cladosporium bruhnei $_{\mathrm{f}, 3}$ \\
\hline Penicillium digitatum $_{\mathrm{f}, 3}$ & Massilia plicata $^{\text {b,-,1 }}$ & - & Cladosporium spp. ${ }^{\mathrm{f}, 3}$ \\
\hline Phoma spp. ${ }^{\mathrm{f}, 3}$ & $\operatorname{Roseomonas~vinaceus~}_{\mathrm{b},-, 1}$ & - & Cladosporium spp. ${ }^{\mathrm{f}, 1}$ \\
\hline- & $\begin{array}{c}\text { Sphingomonas } \\
\text { pseudosanguinis }\end{array}$ & - & Cladosporium ssp. ${ }^{\mathrm{f}, 1}$ \\
\hline- & $\begin{array}{l}\text { Stenotrophomonas } \\
\text { maltophilia }^{\text {b,-,1 }}\end{array}$ & - & $\begin{array}{l}\text { Subplenodomus } \\
\text { valerianae }^{\mathrm{f}, 3}\end{array}$ \\
\hline- & Coriolopsis gallica $^{\mathrm{f}, 1}$ & - & - \\
\hline- & $\begin{array}{l}\text { Rhinocladiella } \\
\text { atrovirens }\end{array}$ & - & - \\
\hline - & Taphrina wiesneri ${ }^{\mathrm{f}, 1}$ & - & - \\
\hline
\end{tabular}

(b) bacteria; (f) fungi; (+) Gram positive; (-) Gram negative; and (1-3) location at Target Book 
aspect in all closed living habitats, including the ISS. To avoid the attachment of bacteria and fungi, the materials should be designed with a smooth surface, either with or without a low content of carbon. In addition, all materials should be tested for their resistance to biological degradation and currently used disinfectants (e.g., hydrogen peroxide, ammonium salts, and urea peroxyhydrate). After the application of highly acrid disinfectants, materials may corrode and become a better substratum again for microorganisms. A solution to this problem could be a milder method of disinfection or the use of biocide materials, which inhibit rapid colonization by microorganisms.

In summary, we report here the colonization and attachment of environmental microorganisms on four different materials (Nomex, CLM, PCB material, and ALU) at the ISS. All four materials were populated by microorganisms, but the highest CFU concentration was obtained on Nomex and CLM. Based on our results, we identified the following genera and species as early populated microorganisms at the sterile Target Book in Zvezda Service Module at the ISS: Staphylococcus spp., Bacillus spp., Streptococcus spp., Cladosporium spp., Sphingomonas spp., Micrococcus luteus, and Stenotrophomonas maltophilia.

\section{ACKNOWLEDGEMENTS}

This work was supported by funding from the project "E-Nose" from Deutsches Zentrum für Luft- und Raumfahrt (DLR) in Bonn, Germany. We gratefully acknowledge cosmonaut Roman Yurievich Romanenko, who performed the experiments at the ISS. Also, we acknowledge the Russian Federal Space Agency, Roscosmos, and the S.P. Korolev Rocket and Space Corporation Energia.

\section{REFERENCES}

Benson DA, Boguski MS, Lipman DJ, Ostell J, Ouellette BF, Rapp BA, Wheeler DL (1999) GenBank. Nucleic Acids Research 27: $12-17$

Bogatova RI, Allen, CS, Kutina IV, Goodman JR (2009) Microclimate, acousitc environment, and lighting conditions. In US and Russian Cooperation in Space Biology and Medicine, A. Nicogossian, O. Gazenko, and A. Grigoriev (ed), pp 237-
248. Washington, D.C.: American Institute of Aeronautics and Astronautics

Castro VA, Thrasher AN, Healy M, Ott CM, Pierson DL (2004) Microbial characterization during the early habitation of the International Space Station. Microbial Ecology 47: 119-126

Cogoli A (1993) Spaceflight and the immune system. Vaccine 11: 496-503

Digestive Ferments Company, Difco Laboratories (1953) Difco Manual of Dehydrated Culture Media and Reagents for Microbiological and Clinical Laboratory Procedures, 9th ed. Detroit, MI: Difco Laboratories

Donlan RM (2002) Biofilms: microbial life on surfaces. Emerging Infectious Diseases 8: 881-890

$\mathrm{Gu}$ JD (2007) Microbial colonization of polymeric materials for space applications and mechanisms of biodeterioration: a review. International Biodeterioration and Biodegradation 1st International Conference on Environmental, Industrial, and Applied Microbiology 59: 170-179

Gu JD (2003) Microbiological deterioration and degradation of synthetic polymeric materials: recent research advances. International Biodeterioration and Biodegradation 52: 69-91

Gu JD, Mitton DB, Ford TE, Mitchell R (1998) Microbial degradation of polymeric coatings measured by electrochemical impedance spectroscopy. Biodegradation 9: $39-45$

Gueguinou N, Huin-Schohn C, Bascove M, Bueb JL, Tschirhart E, Legrand-Frossi C, Frippiat JP (2009) Could spaceflightassociated immune system weakening preclude the expansion of human presence beyond Earth's orbit? Journal of Leukocyte Biology 86: 1027-1038

Horneck G, Klaus DM, Mancinelli RL (2010) Space microbiology. Microbiology and Molecular Biology Reviews 74: 121-156

Kawamura Y, Li Y, Liu H, Huang X, Li Z, Ezaki $T$ (2001) Bacterial population in Russian space station "Mir." Microbiology Immunology 45: 819-828

Klintworth R, Reher HJ, Viktorov AN, Bohle D (1999) Biological-induced corrosion of materials II: new test methods and experiences from Mir station. Acta Astronautica 44: 569-578 
Kuske CR, Banton KL, Adorada DL, Stark PC, Hill KK, Jackson PJ (1998) Small-scale DNA sample preparation method for field PCR detection of microbial cells and spores in soil. Applied and Environmental Microbiology 64: 2463-2472

Mauclaire L, Egli M (2010) Effect of simulated microgravity on growth and production of exopolymeric substances of Micrococcus luteus space and Earth isolates. Federation of European Microbiological Societies Immunology and Medical Microbiology 59: $350-356$

NASA (2012) International Space Station calendar. National Aeronautics and Space Administration (NASA). Retrieved from http://www.nasa.gov/pdf/615398main_201 2_iss_calendar.pdf (Accessed 11/30/14)

Novikova ND (2004) Review of the knowledge of microbial contamination of the Russian manned spacecraft. Microbial Ecology 47: 127-132

Novikova ND, De Boever P, Poddubko S, Deshevaya E, Polikarpov N, Rakova N, Coninx I, Mergeay M (2006) Survey of environmental biocontamination on board the International Space Station. Research in Microbiology 157: 5-12

Novikova ND, Pierson DL, Poddubko SV, Deshevaya YA, Ott CM, Castro VA, Bruce RJ (2009) Microbiology of the International Space Station. In US and Russian Cooperation in Space Biology and
Medicine, A. Nicogossian, O. Gazenko, and A. Grigoriev (ed), pp 263-278. Washington, D.C.: American Institute of Aeronautics and Astronautics

Ott CM, Bruce RJ, Pierson DL (2004) Microbial characterization of free floating condensate aboard the Mir space station. Microbial Ecology 47: 133-136

Ozgen B (2012 ) Physical properties of Kevlar and Nomex plied and covered yarns. Textile Research Journal 83: 752-760

Pierson DL (2001) Microbial contamination of spacecraft. Gravitational and Space Biology Bulletin 14: 1-6

Rakova NM, Svistunova LV, Novikova ND (2005) Studies on the growth and reproduction of bacterial communities on structural materials of the International Space Station. Aviakosmicheskaia i Ekologicheskaia Meditsina 39: 44-46

Viktorov AN, Novikova ND, Deshevaia EA (1992) The cabin microflora of manned space vehicles and the problem of the biological destruction of the construction materials used in them. Aviakosmicheskaia i Ekologicheskaia Meditsina 26: 41-48

White T, Bruns T, Lee S, Taylor J (1990) Amplification and direct sequencing of fungal ribosomal RNA genes for phylogenetics. In PCR Protocols: A Guide to Methods and Applications, M. Innis, D. Gelfand, J. Sninsky, and T. White (ed), pp 315-322. San Diego, CA: Academic Press. 